\title{
Folate-receptor 1 level in periodontal disease: a pilot study
}

\author{
Duygu Alkan ${ }^{1 *}$, Berrak Guven², Cigdem Coskun Turer ${ }^{1}$, Umut Balli $^{1}$ and Murat Can ${ }^{2}$
}

\begin{abstract}
Background: The purpose of this study was to investigate gingival crevicular fluid (GCF) and serum folate-receptor 1 (FOLR1) levels in subjects with different periodontal status.

Methods: The study consists of three groups: Healthy group $(n=15)$, gingivitis group $(n=15)$ and chronic periodontitis group $(n=15)$. Clinical periodontal parameters including probing pocket depth (PPD), clinical attachment level (CAL), gingival index (Gl) and bleeding on probing (BOP) were assessed. GCF and serum samples were collected from each patient and were analyzed FOLR1 levels by enzyme-linked immunosorbent assay.

Results: The values of FOLR1 in GCF were higher in gingivitis and periodontitis groups than among patient in control group $(p<0.016)$. Serum FOLR1 levels showed no significant difference between the groups. A significant correlation was observed between FOLR1 levels of GCF and BOP $(p<0.05)$.

Conclusions: Our preliminary data suggest that FOLR1 is not useful in monitoring the periodontal disease. Further studies are necessary to clarify the role, regulation and function of folate and it's receptors in the pathogenesis of periodontal disease.
\end{abstract}

Keywords: Folate-receptor 1, Periodontitis, Gingivitis

\section{Background}

Periodontal disease is an inflammatory disorder affecting the tooth-supporting tissues which they consists of two types of tissues - epithelial and connective tissue. The tooth-supporting tissues includes the alveolar bone, the periodontal ligament, the cementum, and the gingiva. Gingivitis and periodontitis are the two main periodontal diseases. Gingivitis is a form of periodontal disease in which gingival tissues are inflamed but their destruction is mild and reversible. Periodontitis is a chronic inflammatory status may leading with irreversible changes, such as bone and teeth loss [1]. A variety of factors have been linked with the etiology of periodontitis [2]. Recent studies have suggested that there may also be an association between oral health status and nutritional status. Many nutritients, especially micronutrients contain various vitamins that they are required for oral health maintaining $[3,4]$.

\footnotetext{
* Correspondence: dtduygudurmus@gmail.com

${ }^{1}$ Department of Periodontology, Faculty of Dentistry, Zonguldak Bülent

Ecevit University, Zonguldak, Turkey

Full list of author information is available at the end of the article
}

Folic acid (also known as folate) is a type of B vitamin which participate in one carbon metabolism. It is required for maintaining and production of new cells during development and healing of tissues, because of essential for protein synthesis and deoxyribonucleic acid $[5,6]$. Folate is transported into cells by different transport systems: The reduced folate carrier, low-affinity high-capacity uptake system and the folate receptors (FOLR), low-capacity high-affinity system. Folate-receptor 1 (FOLR1), 38-40 kDa glycosylphosphatidylinositol-anchored glycoprotein, is a well-defined member of the folate receptor family. It mediates folate transportation through receptor-mediated endocytosis [7]. Although FOLR1 expression have been found mostly in epithelial cells, it is often limited in normal epithelial cells [8, 9]. Several studies have reported highly expressed in various tumors of epithelial origin, such as ovarian cancer, lung cancer, breast cancer and high-grade osteosarcoma [10-14]. According to hypothesis of researchers, FOLR1 might contribute to growth of tissue by modulating folate uptake from serum or generating regulatory signals $[15,16]$.

(c) The Author(s). 2019 Open Access This article is distributed under the terms of the Creative Commons Attribution 4.0 International License (http://creativecommons.org/licenses/by/4.0/), which permits unrestricted use, distribution, and reproduction in any medium, provided you give appropriate credit to the original author(s) and the source, provide a link to the Creative Commons license, and indicate if changes were made. The Creative Commons Public Domain Dedication waiver (http://creativecommons.org/publicdomain/zero/1.0/) applies to the data made available in this article, unless otherwise stated. 
Gingival epithelium protects the underlying tissues and it is continuously altered by the inflammatory response in periodontal disease [17]. The regulation of the epithelial barrier play crucial role in periodontal repair/regeneration [18]. In this study, it is theorized that FOLR1 could be important for establishing and maintaining in high cell turnover of epithelium. The constituents of gingival crevicular fluid (GCF) can reflect the changes occurring in underlying epithelial tissue. Therefore, the present study was designed to investigate the FOLR1 levels in GCF and serum samples for healthy, gingivitis and chronic periodontitis participants. In addition, we also evaluated correlations between FOLR1 levels and clinical parameters.

\section{Methods}

\section{Participants}

Participants in this study were selected from patients admitting the Department of Periodontology, Faculty of Dentistry of Bulent Ecevit University. The study was conducted in accordance with the standards of the Ethics Committee of the University of Bulent Ecevit University and with the Helsinki Declaration.

A total of 45 subjects (aged 28-45 years; 23 men; 22 women) were included in this study. Medical and dental histories were taken from all subjects. None of the subjects used any antibiotics or received periodontal treatment within the previous 6 months. Patients with systemic diseases, such as diabetes mellitus, rheumatoid arthritis, obesity, cancer and with history of any medications including vitamin/nutritional supplements were excluded. All of the participants were non-smokers and nonpregnant persons.

All individuals underwent radiography and a fullmouth periodontal examination including probing pocket depth (PPD), clinical attachment level (CAL), gingival index (GI) [19], plaque index [20] and bleeding on probing (BOP) [21]. Clinical parameters were assessed at six sites on each tooth (mesiobuccal, mediobuccal, distobuccal, mesiolingual, mediolingual and distolingual) using a manual periodontal probe (Hu-Friedy, Chicago, IL, USA). All measurements were recorded by the same investigator. Ten people were chosen at random for calibration before the study measurements were taken, and were assessed on two separate occasions 2 days apart. These findings were satisfactorily reproducible, the baseline measurements and measurements taken after $48 \mathrm{~h}$ were within $10 \%$ of each other on the mm scale [22].

Patients were categorized into three groups based on clinical and radiographic criteria proposed by the 1999 International World Workshop for a Classification of Periodontal Disease and Conditions [1].
1- Healthy group: Fifteen subjects had better oral hygiene, no attachment and bone loss ( $\mathrm{GI}=0$, $\mathrm{PPD} \leq 3 \mathrm{~mm}, \mathrm{CAL} \leq 3 \mathrm{~mm}, \mathrm{BOP} \leq 5 \%)$

2- Gingivitis group: Fifteen subjects with gingival inflammation (GI $>1, P P D$ and $C A L ~ \leq 3 \mathrm{~mm}$ and BOP > 5\%).

3- Chronic periodontitis group: Fifteen subjects who had five or more teeth with clinical signs of periodontitis (GI $>1$, PPD and CAL $\geq 5 \mathrm{~mm}$ and BOP $>5 \%$ ), and bone loss affecting $>30 \%$ of the the existing teeth on clinical and radiographic examination.

\section{Collection of samples}

GCF was obtained by a single calibrated investigator from the mesio-buccal or disto-buccal surfaces of single rooted teeth. In all groups, two sites (two teeth, one region of each tooth) per individual were selected for GCF sampling and two samples were taken. All clinical examinations and sampling site selections were performed 2 days before GCF samples collected to prevent the contamination of GCF with blood.

Each crevicular site included in the study was isolated with cotton rolls. After isolating the tooth with a cotton roll and drying with a gentle stream of air to prevent saliva contamination, GCF was sampled with filter paper (PerioPaper, ProFlow, Amityville, NY) using the intracrevicular method [23]. Paper strips were placed into the crevice until mild resistance was felt and were left in position for $30 \mathrm{~s}$. Strips with visible saliva or blood contamination were discarded. Electronic impedance was used to determine the GCF volume of each strip (Periotron 8000; ProFlow Inc., NY, USA) and then was transferred in an empty microcentrifuge tube. Immediately after transference, the paper strips stored at $-40 \mathrm{C}$ until analysis.

In addition, blood samples were drawn from subjects after an overnight fasting. Venous blood samples were collected in 5-mL tubes that did not contain any anticoagulant. Blood samples were centrifuged $(3.000 \mathrm{~g}$ for $10 \mathrm{~min}$ ) to separate the serum component. Serum was stored at $-40{ }^{\circ} \mathrm{C}$ until analysis.

\section{Analytic methods}

Laboratory analyses were performed blind to clinical diagnosis. On the day of the assay, $200 \mu \mathrm{L}$ phosphatebuffered saline ( $\mathrm{pH} 7.4$ ) was added to each of the tubes containing the sample strips. The tubes were vortexed and homogenized for $1 \mathrm{~min}$ and then centrifuged at $3.000 \mathrm{~g}$ for $15 \mathrm{~min}$ at $4{ }^{\circ} \mathrm{C}$. The supernatants were collected for analysis.

FOLR1 levels were assayed by Human FOLR1 kit (Boster, CA, USA) using enzyme-linked immune sorbent assay (ELISA) method. The 96-well plate was coated with $100 \mu \mathrm{L}$ 
of sample (serum or GCF) and were incubated at $37^{\circ} \mathrm{C}$ for $90 \mathrm{~min}$. Plates were discarded and added detection antibody solution $(100 \mu \mathrm{L} /$ well $)$ for $60 \mathrm{~min}$ at $37^{\circ} \mathrm{C}$. Plates were washed three times in wash buffer, substrate solutions were added $(100 \mu \mathrm{l} /$ well $)$ and incubated at $37^{\circ} \mathrm{C}$ protected from light for $30 \mathrm{~min}$. Stop solution $(90 \mu \mathrm{L} /$ well $)$ was added and after $15 \mathrm{~min}$, the optical density was measured at $450 \mathrm{~nm}$. The calibration range of the FOLR1 assay was up to $3000 \mathrm{pg} / \mathrm{ml}$. Results were fitted to the standard curve and presented in the form of picograms per mililiter $(\mathrm{pg} / \mathrm{mL})$.

\section{Statistical analyses}

The sample-size calculations were formulated using the primary outcome variable (GCF FOLR1 levels). We speculated that 14 individuals per group would allow a type I error level of a $=0.05$ (5\% probability) and a type II error level of $b=0.20$ ( $80 \%$ power). Power was determined retrospectively because the population size could not be determined a priori.

All data were analyzed using statistical software (SPSS ver. 19.0; SPSS Inc., Chicago, IL, USA). Statistical analysis was performed using nonparametrical techniques. Comparisons between the study groups were analyzed by employing the Kruskal-Wallis nonparametric test followed by post hoc group comparisons with the Bonferroni-adjusted Mann-Whitney U-test, because the data were not normally distributed. For the Bonferroni correction, $\alpha=0.05 / 3=$ 0.016 was considered to be statistically significant. The correlations between biochemical and clinical parameters were determined by Spearman's correlation coefficient. The results were considered statistically significant when $p$-values were less than 0.05 .

\section{Results}

The clinical parameters and demographic findings are shown in Table 1 . No differences were observed between groups with regards to age and gender $(p>0.05)$. All clinical parameters were differed significantly between groups $(p<0.05)$.

A further 45 GCF samples and 45 paired serum samples from patients were analysed. The mean \pm SD serum FOLR-1 levels were: $373 \pm 364 \mathrm{pg} / \mathrm{ml}$ in healthy group, $375 \pm 392 \mathrm{pg} / \mathrm{ml}$ in gingivitis group and $306 \pm 278 \mathrm{pg} / \mathrm{ml}$ in chronic periodontitis group. The corresponding mean \pm SD GCF FOLR1 levels were: $15.16 \pm 7.25 \mathrm{pg} / \mathrm{ml}$ in healthy group, $37.3 \pm 11.1 \mathrm{pg} / \mathrm{ml}$ in gingivitis group and $37.92 \pm 12.9 \mathrm{pg} / \mathrm{ml}$ in chronic periodontitis group. There was no significant difference in serum FOLR1 concentration between patients and healthy controls $(0.05>$ p). GCF FOLR1 levels were significantly increased in gingivitis and chronic periodontitis patients compared with healthy individuals $(p<0.016)$. No significant
Table 1 Demographic and clinical details of the healthy, gingivitis and chronic periodontitis groups

\begin{tabular}{llll}
\hline & Healthy & Gingivitis & Chronic periodontitis \\
\hline Age $^{*}$ (years) & $35.1 \pm 2.48$ & $35.2 \pm 1.64$ & $36.3 \pm 1.58$ \\
Gender ${ }^{*}(\mathrm{n})$ & 15 & 15 & 15 \\
Male & 7 & 8 & 7 \\
Female & 8 & 7 & 8 \\
$\mathrm{PPD}^{\#}(\mathrm{~mm})$ & $1.50 \pm 0.42$ & $2.18 \pm 0.44$ & $4.83 \pm 0.57$ \\
$\mathrm{CAL}^{\#}(\mathrm{~mm})$ & $1.50 \pm 0.42$ & $2.18 \pm 0.44$ & $5.47 \pm 0.64$ \\
$\mathrm{Gl}^{\#}$ & $0.30 \pm 0.25$ & $1.71 \pm 0.32$ & $2.23 \pm 0.16$ \\
$\mathrm{Pl}^{\#}$ & $0.30 \pm 0.17$ & $1.45 \pm 0.33$ & $1.94 \pm 0.15$ \\
$\mathrm{BOP}^{\#}(\%)$ & $1.80 \pm 0.50$ & $40.7 \pm 9.80$ & $81.8 \pm 6.80$ \\
\hline
\end{tabular}

Data are expressed as the mean \pm SD

Kruskal-Wallis/Bonferroni-adjusted Mann-Whitney

Bonferroni correction $\mathrm{a}=0.05 / 3=0.016$

$P P D$ Probing pocket depth, CAL Clinical attachment loss, GI Gingival index, PI:

Plaque index, $B O P$ Bleeding on probing

${ }^{*}$ No statistical significance difference between group $(P>0.05)$

${ }^{\#}$ Statistical significance difference between group $(P<0.05)$

correlation was found between FOLR1 levels of GCF compared with serum $(r=-0.135, p>0.05)$.

Correlations between FOLR-1 levels and clinical periodontal parameters, including PPD, CAL, GI, PI and BOP were determined as shown in Table 2. There was no correlation between serum FOLR-1 levels and clinical parameters $(p>0.05)$. GCF FOLR-1 concentrations were significantly correlated with BOP scores. GCF FOLR-1 levels were not correlated with another clinical parameters, including PPD, CAL, GI and PI.

\section{Discussion}

Folic acid play a critical role in cellular one carbon metabolism and is important during periods of rapid cell division and growth. Folate deficiency has been shown to be associated with many diseases such as megaloblastic anemia, neural tube defects, cognitive dysfunction and heart disease [24]. Several studies have investigated the significance of folate in periodontitis patients. Erdemir et al. reported that among patients with periodontal disease the serum folic acid concentration is lower in smokers compared with non-smokers [25]. Results from

Table 2 The Spearman's rank correlation ( $r$ ) among clinical parameters and FOLR1 levels

\begin{tabular}{|c|c|c|c|c|}
\hline \multirow{2}{*}{$\begin{array}{l}\text { Clinical } \\
\text { parameters }\end{array}$} & \multicolumn{2}{|c|}{ Serum FOLR-1 levels } & \multicolumn{2}{|c|}{ GCF FOLR-1 levels } \\
\hline & $\bar{r}$ & $p$ & $\bar{r}$ & $p$ \\
\hline$\overline{P P D}$ & -0.27 & 0,24 & 0.30 & 0.19 \\
\hline CAL & -0.22 & 0,35 & 0.35 & 0.13 \\
\hline $\mathrm{PI}$ & -0.32 & 0,17 & 0,36 & 0,11 \\
\hline $\mathrm{Gl}$ & -0.11 & 0,96 & 0.35 & 0.13 \\
\hline $\mathrm{BOP}$ & -0.08 & 0,73 & $0.45^{*}$ & $0.04^{*}$ \\
\hline
\end{tabular}

*Statistically significant $(P<0.05)$ 
the National Health and Nutrition Examination Survey also demonstrated that a low serum folate level was independently associated with periodontal disease in older adults [26]. It's known that folate deficiency is common in older adults and the prevalence of deficiency can increase with age. Even if smoking patients and older adults were not included in our study, it might be feasible to find similar results when serum folate level is measured. However, serum levels of vitamins may not be good at reflecting tissue levels, even though folic acid deficiency is associated with gingival inflammation. Previous studies demonstrated localized folate deficiency that oral tissues need greater folate for maintaining its function in spite of the normal serum folate ranges [27]. Given the importance of folate for periodontal disease, it is reasonable to evaluate transport of folate. In this study, we determined elevated levels of the FOLR1 in GCF released from periodontal tissue. However, this increase was minimal, therefore it did not effect blood levels of FOLR1. On the other hand, GCF FOLR1 level does not totally reflect the degree of clinical parameters in patients with periodontal disease. We only found a positive association between GCF FOLR1 and BOP. This finding is in agreement with previous studies demonstrating a negative association between folic acid intake or level and BOP [26, 28]. Therefore, we assume that the potential increased metabolic requirements for folate could contribute to a rise in FOLR1.

Many clinical research propose folate supplementation for gingival health $[29,30]$. This is called "end-organ deficiency", which were responsive to both topical and systemic folate administration [31]. End organ deficiency is connection with transport systems of folate [27, 32]. Topical administration may be more efficacious compared to systemic administration, because of tend to increase cellular uptake through passive diffusion due to an increased concentration gradient [32, 33]. Despite the potential limitations, our results might be hypothesis generating for future trials. First hypothesis to investigate would be to determine how FOLR1 response to folate supplements.

There are several limitations that should be acknowledged in this preliminary study. We mentioned that plasma folate level was not measured in our study. Second, in the present study, no information on dental health behavior for disease status was used. Third, studies with larger sample size will be required to verify these conjectures.

\section{Conclusions}

Our preliminary data suggest that FOLR1 is not useful in monitoring the periodontal disease. Longitudinal studies with a larger sample should be done to confirm our results. Further studies are necessary to clarify the role, regulation and function of folate and it's receptors in the pathogenesis of periodontal disease.

\section{Abbreviations}

BOP: Bleeding on probing; CAL: Clinical attachment level; ELISA: Enzyme linked immune sorbent assay; FOLR1: Folate receptor 1; GCF: Gingival crevicular fluid; Gl: Gingival index; PI: Plaque index; PPD: Probing pocket depth; SD: Standart deviation; SPSS: Statistical package for social science

\section{Acknowledgements}

Not applicable.

\section{Authors' contributions}

CT and UB: Recruitment of patients and volunteers; site selection; periodontal examination; GCF sample collections. DD, BG and MC: Measurement of FOLR1 levels, statistical analyses, manuscript preparation and corresponding author. All authors have reviewed and agreed to the submission of the revised manuscript.

\section{Funding}

The study was self-funded by the authors.

\section{Availability of data and materials}

The datasets used and/or analysed during the current study are available from the corresponding author on reasonable request.

\section{Ethics approval and consent to participate}

The present study was approved by the Medicine Research Ethics

Committee of the Bulent Ecevit University Faculty (Protocol No: 2018-133-09/

05). Informed written consent was obtained from all individual participants included in the study.

Consent for publication

Not applicable.

\section{Competing interests}

The authors declare that they have no competing interests.

\section{Author details}

${ }^{1}$ Department of Periodontology, Faculty of Dentistry, Zonguldak Bülent Ecevit University, Zonguldak, Turkey. ${ }^{2}$ Department of Biochemistry, Faculty of Medicine, Zonguldak Bülent Ecevit University, Zonguldak, Turkey.

Received: 25 October 2018 Accepted: 13 September 2019

Published online: 11 October 2019

\section{References}

1. Armitage GC. Development of a classification system for periodontal diseases and conditions. Ann Periodontol. 1999;4(1):1-6. https://doi.org/10. 1902/annals.1999.4.1.1.

2. Nunn M. Understanding the etiology of periodontitis: an overview of periodontal risk factors. Periodontol 2000. 2003;32:11-23. https://doi.org/10. 1046/j.0906-6713.2002.03202.x.

3. Dodington DW, Fritz PC, Sullivan PJ, Ward WE. Higher intakes of fruits and vegetables, beta-carotene, vitamin C, a-tocopherol, EPA, and DHA are positively associated with periodontal healing after nonsurgical periodontal therapy in nonsmokers but not in smokers. J Nutr. 2015;145:2512-9. https://doi.org/10.3945/jn.115.211524.

4. Ritchie CS, Kinane DF. Nutrition, inflammation, and periodontal disease. Nutrition. 2003;19:475-6. https://doi.org/10.1016/S0899-9007(02)01043-2.

5. Stabler SP. B12 and nutrition. In: Banerjee R, editor. Chemistry and biochemistry of B12. New York: Wiley; 2000. p. 343-65.

6. Babior BM, Bunn HF. Megablostic anemias. In: Kasper DL, Braunwald E, Fauci AS, et al., editors. Harrison's principles of internal medicine. New York: The McGraw-Hill Companies Inc; 2005. p. 601-6.

7. Elnakat $H$, Ratnam M. Distribution, functionality and gene regulation of folate receptor isoforms: implications in targeted therapy. Adv Drug Deliv Rev. 2004;56:1067-84. https://doi.org/10.1016/j.addr.2004.01.001.

8. Kamen BA, Smith AK. A review of folate receptor alpha cycling and 5methyltetrahydrofolate accumulation with an emphasis on cell models in vitro. Adv Drug Deliv Rev. 2004;56:1085-97. https://doi.org/10.1016/j.addr. 2004.01.002 
9. Zhao R, Diop-Bove N, Visentin M, Goldman ID. Mechanisms of membrane transport of folates into cells and across epithelia. Annu Rev Nutr. 2011;31: 177-201. https://doi.org/10.1146/annurev-nutr-072610-145133.

10. Parker N, Turk MJ, Westrick E, Lewis JD, Low PS, Leamon C. Folate receptor expression in carcinomas and normal tissues determined by a quantitative radioligand binding assay. Anal Biochem. 2005;338:284-93. https://doi.org/ 10.1016/j.ab.2004.12.026

11. Toffoli G, Russo A, Gallo A, Cernigoi C, Miotti S, Sorio R, et al. Expression of folate binding protein as a prognostic factor for response to platinumcontaining chemotherapy and survival in human ovarian cancer. Int J Cancer. 1998;79:121-6. https://doi.org/10.1002/(SICI)1097-0215(19980417)79: 2\%3C121::AID-IJC4\%3E3.0.CO;2-V.

12. Bueno $R$, Appasani $K$, Mercer $H$, Lester $S$, Sugarbaker D. The alpha folate receptor is highly activated in malignant pleural mesothelioma. J Thorac Cardiovasc Surg. 2001;121:225-33. https://doi.org/10.1067/mtc.2001.111176.

13. Hartmann LC, Keeney GL, Lingle WL, Christianson TJ, Varghese B, Hillman D, et al. Folate receptor overexpression is associated with poor outcome in breast cancer. Int J Cancer. 2007;121:938-42. https://doi.org/10.1002/ijc.22811.

14. Yang R, Kolb EA, Qin J, Chou A, Sowers R, Hoang B, et al. The folate receptor alpha is frequently overexpressed in osteosarcoma samples and plays a role in the uptake of the physiologic substrate 5methyltetrahydrofolate. Clin Cancer Res. 2007;13:2557-67. https://doi.org/10. 1158/1078-0432.CCR-06-1343.

15. Kane MA, Elwood PC, Portillo RM, Antony AC, Najfeld V, Finley A, Waxman S, Kolhouse JF. Influence on immunoreactive folate-binding proteins of extracellular folate concentration in cultured human cells. J Clin Invest. 1988;81(5):1398-406. https://doi.org/10.1172/JCl113469.

16. Miotti S, Bagnoli M, Tomassetti A, Colnaghi Ml, Canevari S. Interaction of folate receptor with signaling molecules lyn and $G(a l p h a)(i-3)$ in detergentresistant complexes from the ovary carcinoma cell line IGROV1. J Cell Sci. 2000;113(Pt 2):349-57.

17. Dale BA. Periodontal epithelium: a newly recognized role in health and disease. Periodontology. 2002;30:70-8. https://doi.org/10.1034/j.1600-0757. 2002.03007.x.

18. Fujita T, Yoshimoto T, Kajiya M, Ouhara K, Matsuda S, Takemura T, Akutagawa K, Takeda K, Mizuno N, Kurihara H. Regulation of defensive function on gingival epithelial cells can prevent periodontal disease. Jpn Dent Sci Rev. 2018;54(2):66-75. https://doi.org/10.1016/j.jdsr.2017.11.003.

19. Loe $H$, Silness J. Periodontal disease in pregnancy. I. Prevalence and severity. Acta Odontol Scand. 1963;21:533-51.

20. Silness J, Loe H. Periodontal disease in pregnancy. li. Correlation between oral hygiene and periodontal condition. Acta Odontol Scand. 1964;22:121-35.

21. Ainamo J, Bay I. Problems and proposals for recording gingivitis and plaque. Int Dent J. 1975;25:229-35.

22. Schwarz F, Bieling K, Latz T, Nuesry E, Becker J. Healing of intrabony periimplantitis defects following application of a nanocrystalline hydroxyapatite (Ostim) or a bovine-derived xenograft (Bio-Oss) in combination with a collagen membrane (Bio-Gide). A case series. J Clin Periodontol. 2006;33: 491-9.

23. Griffiths GS. Formation, collection and significance of gingival crevice fluid. Periodontol 2000. 2003;31:32-42. https://doi.org/10.1034/j.1600-0757.2003. 03103.x.

24. Bender DA. Nutritional biochemistry of the vitamins (2nd). Cambridge: Cambridge University Press; 2003. p. 270-94.

25. Erdemir EO, Bergstrom J. Relationship between smoking and folic acid, vitamin B12 and some haematological variables in patients with chronic periodontal disease. J Clin Periodontol. 2006;33(12):878-84. https://doi.org/ 10.1111/j.1600-051X.2006.01003.X.

26. Yu YH, Kuo HK, Lai YL. The association between serum folate levels and periodontal disease in older adults: data from the National Health and Nutrition Examination Survey 2001/02. J Am Geriatr Soc. 2007;55(1):108-13. https://doi.org/10.1111/j.1532-5415.2006.01020.x.

27. Heimburger DC. Local deficiencies of folic acid in aero-digestive tissues. Ann N Y Acad Sci. 1992;669:87-95.

28. Esaki M, Morita M, Akhter R, Akino K, Honda O. Relationship between folic acid intake and gingival health in non-smoking adults in Japan. Oral Dis. 2010;16(1):96-101. https://doi.org/10.1111/j.1601-0825.2009.01619.x.

29. Thomson ME, Pack AR. Effects of extended systemic and topical folate supplementation on gingivitis of pregnancy. J Clin Periodontol. 1982;9(3): $275-80$.
30. Pack AR. Effects of folate mouthwash on experimental gingivitis in man J Clin Periodontol. 1986;13(7):671-6.

31. Vogel RI, Fink RA, Schneider LC, Frank O, Baker $H$. The effect of folic acid on gingival health. J Periodontol. 1976;47:667-8.

32. Brown RS, Arany PR. Mechanism of drug-induced gingival overgrowth revisited: a unifying hypothesis. Oral Dis. 2015;21(1):e51-61. https://doi.org/ 10.1111/odi.12264

33. Drew HJ, Vogel Rl, Molofsky W, Baker H, Frank O. Effect of folate on phenytoin hyperplasia. J Clin Periodontal. 1987;14:350-6.

\section{Publisher's Note}

Springer Nature remains neutral with regard to jurisdictional claims in published maps and institutional affiliations.
Ready to submit your research? Choose BMC and benefit from:

- fast, convenient online submission

- thorough peer review by experienced researchers in your field

- rapid publication on acceptance

- support for research data, including large and complex data types

- gold Open Access which fosters wider collaboration and increased citations

- maximum visibility for your research: over $100 \mathrm{M}$ website views per year

At BMC, research is always in progress.

Learn more biomedcentral.com/submissions 